\title{
Nontimber forest products as ecological and biocultural keystone species
}

\author{
Charlie M. Shackleton $^{1}$, Tamara Ticktin ${ }^{2}$ and Anthony B. Cunningham ${ }^{3,4}$
}

\begin{abstract}
Nontimber forests products (NTFPs) are the mainstay of rural livelihoods and local economies the world over. As such they are of interest to a wide disciplinary range of researchers and development and government agencies seeking to promote livelihoods, incomes, and ecologically sustainable practices. With the attention on the various human uses of NTFPs, their role and networks in the broader biological communities in which they are located are frequently overlooked. Harvesting of many NTFPs has effects not only at the organism and population scales, but also on co-occurring species, some of which may also be NTFPs. Thus, reduction or loss of one NTFP population or species in a specific area may have cascade effects on other NTFP species, including those used for cultural purposes. We illustrate the little appreciated importance of NTFPs in broader ecological and social systems by assessing and illustrating the importance of NTFP species as ecological or biocultural keystones in providing regulating and supporting ecological services to other species and cultural services to people. We present a number of examples where NTFP species act as keystones in ecological and cultural systems, including food, pollination and dispersal, animal health, nutrients, shelter and protection, and cultural symbolism, most of which have not been considered by NTFP researchers and practitioners. From these examples we distill six propositions regarding NTFPs and discuss the value of recognizing some NTFPs as biocultural keystones to acknowledge and highlight their roles at broader scales.
\end{abstract}

Key Words: culture; food; health; keystone species; nutrients; pollination; shelter

\section{INTRODUCTION}

The use of nontimber forest products (NTFPs) is deeply embedded in socio-cultural and economic systems worldwide, both in rural (Belcher et al. 2005, Angelsen et al. 2014, Wahlén 2017) and urban communities (Schlesinger et al. 2015, Shackleton et al. 2017, Hurley and Emery 2018). NTFP use fulfils multiple livelihood functions, including directly providing consumptive goods, saving cash on substitute goods, safety nets during adverse periods, income generation from sale, and maintaining cultural traditions and knowledge (Shackleton 2015). Societies and cultures mediate NTFP contributions to these functions and knowledge domains shaping their use and management, in terms of which species are selected, by who, when, and how and where they are found. NTFP systems are duly complex, and can be placed within standard framings of social-ecological systems (SES; Fig. 1). Most SES depictions and analyses consider interactions between domains, with little attention to interactions within domains, e.g., between different actors such as governance agencies; or, here, between different NTFP species and functions. Both inter- and intradomain interactions are shaped by, and contribute to shaping, interactions at the larger SES scale. For example, beliefs, culture, traditions, and values around NTFPs then contribute to the nature of governance systems.

The myriad species involved, their extensive use, social embeddedness, and cultural value (often to marginalized groups), has prompted much research and policy attention from several social science disciplines seeking to promote equitable access, income, benefit sharing, and maintenance of cultural values (e.g., Shackleton et al. 2011, Kar and Jacobsen 2012, Kassa and Yigezu 2015, Coomes et al. 2016). Yet most social science literature on the use and value of NTFPs rarely acknowledges or examines the broader ecological role of the species. This is potentially problematic when well-meaning external agencies initiate widerscale NTFP commercialization initiatives with insufficient understanding of broader ecological linkages beyond the target species.

Fig. 1. Nontimber forest products (NTFPs) in social-ecological systems. Figure adapted from McGinnis and Ostrom (2014) by replacing "resources units" with NTFPs. The original does not delineate interactions within the four domains (only between them). Here we illustrate how the within interactions, i.e., use of and interactions between NTFP species, affects other NTFPs and uses, i.e., the biocultural keystone roles.

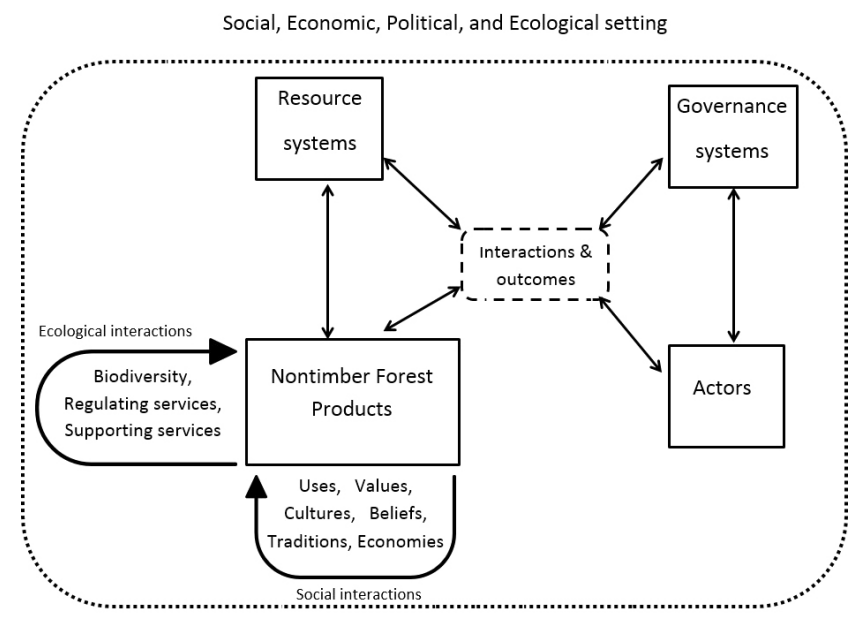

\footnotetext{
${ }^{1}$ Rhodes University, ${ }^{2}$ Department of Botany, University of Hawai'i at Mānoa, ${ }^{3}$ School of Life Sciences, University of KwaZulu-Natal, South Africa,
} ${ }^{4}$ Murdoch University, Australia 
Similarly, while ecological dynamics and productivity have been studied for many NTFP species, academic and conservation discourse rarely situates species of interest in their ecological or social contexts (Shackleton 2015), and does not consider their broader significance in providing other ecological or cultural goods and services. Most studies attempting to determine sustainable harvest levels for NTFP species consider only how much could be used by people (e.g., Endress et al. 2006, Ghimire et al. 2008), overlooking that many NTFPs also provide services to other species within the ecological community. Likewise, many studies assessing impacts of people harvesting NTFPs rarely consider the impacts of other processes (e.g., fire, land transformation) or species (competitors, invasives) on the life cycle of the NTFP species at individual or population scales (Ticktin 2004; exceptions include Mandle and Ticktin 2012, Ticktin et al. 2012, Sinasson et al. 2017).

In wishing to characterize the importance of NTFPs in the ecological and cultural communities in which they are located, harvested, and managed, we propose that the concept of biocultural keystone species be used. The keystone species construct has been used in ecological and conservation literature and policies for decades (e.g., Paine 1969, Power and Mills 1995, Power et al. 1996, Peres 2000, Helfield and Naiman 2006, CotteeJones and Whittaker 2012, Valls et al. 2015). The term most commonly describes a species with disproportionately large influence on community dynamics relative to its abundance (Power et al. 1996, Cottee-Jones and Whittaker 2012). Consequently, removal or decline of a keystone species in a community is likely to result in the reduced abundance of one or more other species, even entire guilds, in that community. Extreme cases may develop coextinctions, as in Singapore, where the extinction of butterfly species followed the loss of host plant species (Koh et al. 2004), or New Zealand, where reduced density and reproduction of the shrub Rhabdothamnus solandri followed the loss of two pollinating bird species (Colwell et al. 2012). The keystone concept has also been applied at larger scales such as keystone communities (Mouquet et al. 2012), keystone habitats (Davidar et al. 2001), and hyperkeystones (Worm and Paine 2016).

There are two major limitations in the ecological literature on keystone species. The first is the disproportionate number of studies on food dependencies (see Table 1 in Power et al. 1996), relative to the number of studies on other types of interspecific relationships, e.g., shelter, health, or dependencies of people on species and vice-versa. We are not aware of any study that has systematically considered all or multiple potential keystone offerings of one or more species within a single community, the closest being Manning et al.'s (2006) work on isolated trees as keystone structures. We address this to some extent here. We also go beyond ecological services by considering the cultural services provided by keystone species, i.e., seeing them as constituents of SES, emphasized by our focus on NTFPs. The second limitation is the dearth of work on keystones in urban settings, one exception being Caughlin et al.'s (2012) study on sacred fig trees in Indian cities. Because of this limitation, our argument uses examples from rural communities.

The concept of keystone species has also been adapted to social disciplines as cultural keystone species, defined by Garibaldi and
Turner (2004) as "culturally salient species that shape in a major way the cultural identity of a people, as reflected in ... diet, materials, medicine, and/or spiritual practices," or by Cristancho and Vining (2004:155) as "species whose existence and symbolic value are essential to the stability of a cultural group over time." Some species may be considered both cultural and ecological keystones (Cristancho and Vining 2004, Garibaldi and Turner 2004), and thus provide unique opportunities for bridging between social and ecological perspectives in natural resource use policies, planning, and management (Poe et al. 2014).

The cultural keystone species concept and approaches for measurement have been tested in only a few studies (e.g., Garibaldi 2009, Butler et al. 2012). Garibaldi and Turner (2004) list six core attributes of the cultural keystone concept (Cristancho and Vining 2004 list seven strongly similar attributes) concerning the integration of animal, plant, or biodiversity features and sites into (i) intensity, type, and multiplicity of use, (ii) naming in language, (iii) ceremonial and symbolic roles, (iv) persistence in memory following cultural change, (v) uniqueness or irreplaceability in a culture, and (vi) extent it drives demand for that species beyond local provision. Ranking species within each category and then summing the ranks across all six provides a quantitative score of the relative magnitude of each cultural keystone species.

Drawing from the above, we aim to illustrate the importance of NTFPs in broader SES by assessing NTFP species as biocultural keystones providing ecological services to biological communities, and cultural services to people. In this paper, we (i) argue the ecological value of NTFPs beyond commonly attributed social values, (ii) bring together the ecological and social constructs of keystone species, and (iii) apply the keystone dependencies to a wide variety of services provided by keystone species. We present a number of examples where NTFP species act as biocultural keystones in local ecologies and/or cultures, using a range of examples and dependencies, including some that have hardly been studied. From these examples we distil six propositions regarding NTFPs and discuss the value of recognizing some NTFPs as biocultural keystones.

\section{NTFPS AS BIOCULTURAL KEYSTONE SPECIES}

\section{Food}

Food is a core element of many cultures, and the importance of edible NTFP species is reflected in their maintenance and use in cultural traditions (e.g., Bonta et al. 2006, Assogbadjo et al. 2012). Many NTFP species produce resources, fruit, flowers, seeds, nectar, leaves, bark, exudates, wood, consumed by other members of the ecological community and humans. Although there is debate over which species should be considered ecological keystones (Peres 2000, Stevenson 2005), some species that are exceptionally important community food sources are also heavily harvested NTFPs.

Palms are a good example of a biocultural keystone: they are often considered ecological keystones because several species supply large quantities of highly nutritious fruit year round to a wide variety of organisms (Terborgh 1986, Snyder et al. 1987, Peres 2000), and are also among the most useful plant groups to people worldwide. Many are heavily harvested for fruits, leaves, fibres, and apical meristems (Eiserhardt et al. 2011). Numerous studies modeling the effects of fruit harvest on palm population 
dynamics have shown that they can support high levels of harvest without population decline (e.g., Bernal 1998, Sampaio and dos Santos 2015, see review by Ticktin 2015). Heavy and consistent fruit harvest can, however, potentially affect frugivores dependent on palms, but this is rarely considered.

The only study experimentally testing the effects of fruit harvest on frugivore populations was carried out on acai (Euterpe oleracea), an ecological keystone providing food to a range of frugivores during scarce periods (Moegenburg and Levey 2003). Acai palm is important to people locally and globally; the fruit juice is a staple in the regional diet, and the antioxidant-rich fruits are exported worldwide. Moegenburg and Levey (2003) showed that heavy harvest of acai fruit decreased abundance and diversity of avian frugivores, richness of mammalian frugivores, and changed the species composition of frugivorous birds. Conversely, enrichment plantings supported more fruit-eating birds, shifting the avian community composition toward fruit-eaters.

Some NTFP species have specialized relationships with consumers that may be particularly sensitive to high harvest rates: Buriti palm (Mauritia flexuosa) is an ecological keystone (Peres 2000) with fruit consumed by a wide range of birds, rodents, mesomammals, and reptiles (Bodmer 1991, Zona 2005, Villalobos and Bagno 2012), as well as humans. Red-bellied Macaw (Orthopsittaca manilata), a dietary specialist feeding almost exclusively on ripe buriti fruit (Silva 2009, as cited in Sampaio and dos Santos 2015), is affected by heavy buriti harvest. In Brazil, harvesters typically collect fruit from the ground (Sampaio and dos Santos 2015), while in Peru, harvest involves felling the trees (Gilmore et al. 2013). Collecting fallen fruit allows at least avian frugivores to feed from the canopy, while felling potentially puts specialists, such as Red-bellied Macaws, at risk.

Declines in frugivore populations can potentially impact the population dynamics of NTFPs (Forget and Jansen 2007), and for frugivores that are also seed dispersers, any such declines may also alter patterns and rates of seed dispersal of other species (Bodmer 1991, Villalobos and Bagno 2012). Frugivorous seed dispersers of buriti such as peccaries, tapirs and brocket deer are also heavily hunted, which can further reduce dispersal. Fruit harvest and hunting by humans can thus create a negative feedback loop for both plants and their frugivores.

Tree species that produce high quantities of nutritious fruit tend to be important food sources for both animals and people: the majority of forest fruits collected by people are also eaten by large mammals and birds (Hladik et al. 1993). In northern South Africa, baboons consume up to $85 \%$ of baobab fruit (Adansonia digitata; Venter and Witowski 2011), about the same percentage as that removed by people in areas where the fruit is commercialized (Welford et al. 2015). Fruit harvest by people may be sustainable in terms of baobab population persistence (Venter and Witowski 2013), but the consequences for frugivore populations remain unexplored.

Species or genera that are critical food resources in one ecological community may not be so in another, even those nearby. Instead, the strength of ecological interactions for a given species tends to be context-dependent (Peres 2000, Stevenson 2005, Caro 2010). For example, Euterpe edulis, harvested for its apical meristems (palm hearts), is widely regarded as a keystone resource for birds in the Atlantic forests, where it fruits at a time of scarcity; however, it shows fruiting redundancy elsewhere (Peres 2000). In South Indian dry forests, frugivory rates for amla (Phyllanthus emblica), a tree fruit commercially harvested for food and medicine, differ greatly across two neighboring forest reserves: up to $100 \%$ of fruit are regularly consumed in one (Prasad and Sukumar 2010), compared to only $20-55 \%$ in the other (Ticktin et al. 2012, 2014).

Finally, food chain interactions are complex, and even heavy harvest of food sources from keystone species do not automatically lead to declines in consumer populations (Galetti and Aleixo 1998). Frugivores may migrate, or switch food resources, depending on the availability of other food sources (Moegenburg and Levey 2003). Clearly, this area of research is ripe for further exploration.

\section{Pollination and dispersal}

Pollinators and dispersers play critical roles in the long-term survival of plant populations. Dispersal can promote plant recruitment by allowing seeds to escape predation, by transporting them to potentially favorable microsites for germination, and/or by promoting seed survival and germination through depulping or gut passage (Kurten 2013; Fig. 2). Many of these animals are also important for the nutrition, household economics, and culture of local communities. Because approximately three-quarters of plant species in the tropics are dispersed by animals, defaunation due to hunting of these pollinator and disperser species may have complex, cascading effects on multiple species and ecosystem processes and will likely have significant, though variable, impacts on plant populations (see reviews by Wright 2003, Stoner et al. 2007, Kurten 2013).

Fig. 2. The interactions between fruit production, seed predation, seed dispersal, and recruitment (a), and how these are altered through nontimber forest product (NTFP) use of either fruits, seeds, or hunting of vertebrate dispersers (b).

a)

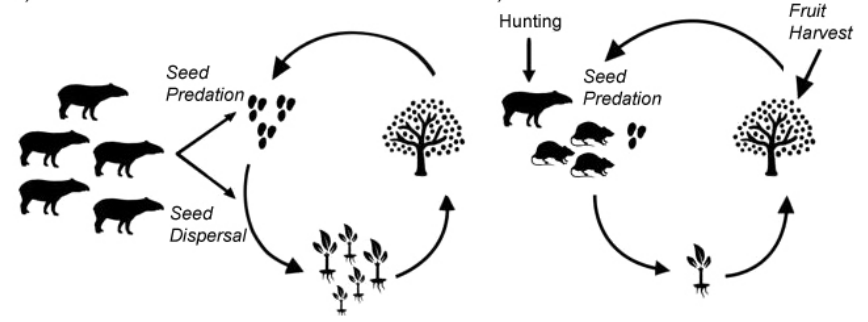

Many animals hunted for food, medicine, and ritual use are frugivores and important seed dispersers (Peres and Palacios 2007, Butchart 2008, Williams et al. 2014). For example, in Asian tropical forests, the largest group of avian frugivores and dispersers are hornbills (Kitamura 2011). They are hunted for their meat and body parts, which have traditional uses (Bennett et al. 1997, Naniwadekar et al. 2015). In Northeast India, logging and the hunting of hornbills has reduced hornbill populations, and reduced scatter dispersal in large-seeded trees (Naniwadekar et al. 2015). The limited data indicates that defaunated forests show lower abundance of bird-dispersed trees (Kurten 2013).

Likewise, bats are also heavily hunted for local and commercial purposes in many regions (Mickelburgh et al. 2009), which can 
affect their roles as pollinators and dispersers (Scanlon et al. 2014, McConkey and Drake 2015). This is expected to have major impacts on the persistence of many species of plants, including NTFPs valued by people, yet the indirect effects of bat hunting are poorly explored. In many isolated Oceanic islands, where pollinator-disperser guilds are depauperate, flying foxes (Pteropus $\mathrm{sp}$.) are considered keystones but their populations are in decline, due largely to hunting and habitat loss (IUCN 2014). In Tonga, they are the sole effective disperser for $57 \%$ of the seeds they disperse (McConkey and Drake 2015); in Fiji, bats pollinate or disperse $42 \%$ of total plants, and $96 \%$ of culturally important plants (Scanlon et al. 2014), including cultural keystone species such as Pandanus tectorius.

Hunting of large vertebrates can also reduce seed dispersal, especially for large seeds (Stoner et al. 2007, Kurten 2013), because large-seeded species are dispersed by a subset of large-bodied vertebrates. However, large-bodied vertebrate dispersers are also often major seed predators, so in some cases hunting can also lead to lower rates of seed predation and higher seed germination, countering the negative effects of loss of dispersal (Stoner et al. 2007, Kurten 2013). This compensatory effect may not hold where plant NTFP harvest occurs in conjunction with hunting. This is of potential concern, because NTFP species most heavily harvested for their fruit also tend to be species with large seeds. In addition, large vertebrates suffer disproportionately heavy hunting pressure compared to smaller ones, and are vulnerable to population decline, both because they are preferred game species (Peres and Palacios 2007) and because of late age of first reproduction and lower fecundity (Cardillo et al. 2005). The hunting of large mammals, whether for commercial or subsistence purposes, is largely unsustainable (Milner-Gulland and Bennett 2003, Peres and Palacios 2007).

Forget and Jansen (2007) showed that hunting may also contribute to recruitment failure, with disproportionately large effects on trees with high seed crops (Fig. 2). In Carapa procera, an Amazonian tree heavily harvested for its seeds (Plowden 2004), the seeds depend on scatter-hoarding rodents, and have negligible chances of recruitment without dispersal. For many plant species, when a principal seed dispersal agent is extirpated, dispersal is not equally compensated by other dispersers (Kurten 2013).

Hunting may also indirectly increase seed predation by insects and/or nonhunted granivorous vertebrates (Stoner et al. 2007). The harvested plants receive a triple blow: their seeds are harvested, and with hunting, the remaining ones may be both less dispersed and more highly predated. Overall, defaunated forests frequently show shifts toward lower species richness and diversity (Kurten 2013). This decrease can have also impacts on the availability of plant NTFPs.

\section{Health}

Some plant species are of great importance to the health of other species, including humans as well as pollinators and dispersers. Unlike trophic relationships and keystone species, many of these services and inter-relationships are poorly known and little researched.

Latex-producing plants, logging, and the health of bee colonies The contribution of plant exudates with antibacterial and antimicrobial properties to the health of important pollinators such as honeybees and stingless bees has escaped most scientific attention. This is surprising given the high economic value of pollination services, estimated in 2005 at $€ 153$ billion, or $9.5 \%$ of the world's food production (Gallai et al. 2009). In their otherwise comprehensive review of drivers of global pollinator declines, Potts et al. (2010) overlook the role of plant exudates to propolis chemistry or hive health.

Colonial bees use exudates from specific plant families and genera in building their hives. The latex of many tree species favored as sources of exudate for hive construction by stingless bees contain antimicrobial and antibacterial compounds such as xanthones, benzophenones, and terpenoids (de Castro Ishida et al. 2011). These include xanthones from Asian and African Garcinia species (Clusiaceae; Deachathai et al. 2005, Sanpa et al. 2015); terpenoids from Spirostachys africana (Euphorbiaceae; Mathabe et al. 2008) and Ficus congensis (Moraceae; Alaribe et al. 2011); and benzophenones from Clusia grandiflora (Clusiaceae), which bioassays show to be particularly effective against honeybee pathogens Paenibacillus larvae and P. alvei (Lokvam 2000).

The same exudate-producing plant families are also widely used by local people in traditional medicine (Ho 1999). Indigenous people across the tropics, for whom stingless bees (Trigonidae) and honeybees (Apidae, Apis mellifera) are cultural keystones (Posey 2002, Mguni 2006), are well aware of the bees' preference for these tree species. In southern Africa, for example, latex of Spirostachys africana and Garcinia livingstonei is so attractive to stingless bees that local people use twigs from these trees to follow bees to their nests (Cunningham 1985).

We suggest that along with the various factors mentioned by Potts et al. (2010), specific exudate-producing plant families (Clusiaceae, Euphorbiaceae, Moraceae) and particular genera within them (such as Clusia, Garcinia, Spirostachys) play a disproportionately important role as sources of antibacterial and antimicrobial exudates used by bees, and that selective logging of such latex-producing species may be affecting hive health (Cunningham et al. 2005, Cunningham 2015).

Plant medicines used by animals: zoopharmacognosy

Ethnobotanists (Johns 1990) and primatologists (Huffman 1996) provide convincing arguments that use of medicinal plants by nonhuman primates are at the roots of traditional medical practices by people. Among the best-known examples are the use of plants such as Vernonia amygdalina to treat internal parasites (Huffman 1996). What is rarely considered, however, are the implications for nonhuman primates (or other animals) when the medicinal plants they use for self-medication are overexploited by people. This is unlikely to happen with $V$. amygdalina populations because this species is relatively fast growing, common, and widespread in Africa. But there are cases where conservation concerns and use for medication by wildlife, people, and/or their livestock coincide.

In the Karakoram Mountains, for example, local people use roots of the endangered endemic shrub Berberis pseudumbellata subsp. gilgitica to treat themselves and their livestock. The same species is used by birds such as the Himalayan Snowcock (Tetraogallus himalayensis) and ungulates, e.g., the Himalayan ibex (Capra ibex sibirica) and flare-horned markhor (Capra falconeri falconeri) for self-medication (Khan et al. 2014). Thus, the health of all could 
Table 1. Examples of cultural keystones across a range of taxa with multiple roles or links in their ecological community.

\begin{tabular}{|c|c|}
\hline Cultural keystones & Roles/dependencies in ecological communities \\
\hline Aardvarks (Orycteropus afer) & $\begin{array}{l}\text { Excavates large burrows that are used by nonburrowing species for refuge (e.g., warthogs, porcupines, snakes) } \\
\text { and breeding /nesting (warthogs, African wild dogs [Lycaon pictus], Blue Swallows [Hirundo atrocaerulea], Ant- } \\
\text { eating Chat [Myrmecocichla formicivora]). } \\
\text { Sole disperser of seeds of the aardvark cucumber (Cucumis humifructus). } \\
\text { Excavated soil is a primary germination site for several species as the soil is turned over and the site is less prone } \\
\text { to wild fires. }\end{array}$ \\
\hline Caapi (Banisteriopsis spp.) & $\begin{array}{l}\text { Flowers secrete oils that are collected by specific hymenoptera species, which are also pollinators. } \\
\text { In turn, the ants also tend/protect the larvae of several lycaenid butterfly species. }\end{array}$ \\
\hline $\begin{array}{l}\text { Marula (Sclerocarya birrea subsp. } \\
\text { caffra) }\end{array}$ & $\begin{array}{l}\text { Primary host of two mistletoes species that are also harvested as NTFPs. } \\
\text { Commonly hosts hole-nesting bird species such as barbets and hornbills. } \\
\text { Large quantities of fallen fruit is consumed by a variety of vertebrate and invertebrate animals (primates, } \\
\text { millipeds, antelope). } \\
\text { Alters the subcanopy habitat, conditions that suit palatable herbaceous species that become favored spots for } \\
\text { grazing by wild game. } \\
\text { Bark and leaves eaten by elephant. }\end{array}$ \\
\hline Vultures (several species) & $\begin{array}{l}\text { Rapid consumption of carcasses limits accumulation of pathogens and transmission to other scavenger species. } \\
\text { Soil nutrient enrichment beneath nesting sites leading to altered herbaceous species. } \\
\text { Soil nutrient enrichment beneath nesting sites resulting in higher diversity of soil biota. }\end{array}$ \\
\hline Pacific salmon (Oncorhynchus spp.) & $\begin{array}{l}25 \% \text { of the nitrogen budget in the riparian zone. } \\
\text { Salmon carcasses are a vital food resource for many microinvertebrate species such that density increases rapidly } \\
\text { when salmon carcasses are available. } \\
\text { Significant food source for several large vertebrates such as bears, otters, and eagles. }\end{array}$ \\
\hline
\end{tabular}

be compromised if B. pseudumbellata subsp. gilgitica populations decline on account of human extraction if no substitutes exist in the area. Another example is Prunus africana, the only African representative of its genus, and also Africa's most lucrative and largest medicinal plant export by volume. $P$. africana leaves are an important component in the diet of rare primates such as red colobus (Chapman et al. 2003) and black-and-white colobus (Fashing 2004), and the folk medicine of many indigenous peoples (Abera 2014). With almost all $P$. africana bark wild-harvested, there are serious conservation concerns about unsustainable harvest (Cunningham et al. 2016). Despite the ecological connections between $P$. africana and wildlife being raised over 20 years ago (Cunningham and Mbenkum 1993), commercial bark exploitation in national parks continues.

\section{Nutrient cycling}

The flow of nutrients between trophic levels is key to ecosystem functioning. All organisms accumulate nutrients and release them directly back to the environment through excretion, decomposition, or indirectly through the food chain. However, various species may contribute disproportionately to either nutrient pools or nutrient cycling, and in generally dystrophic systems, e.g., tundra, nutrient-poor savannas, or deserts, such species can often be regarded as keystones.

Foundation species, those that have both large influence and large abundance (Cottee-Jones and Whittaker 2012), are important in this regard, because they constitute a major proportion of ecosystem biomass and are key nutrient sinks (Orwig et al. 2013) that capture, concentrate, and recycle significant proportions of community nutrient pools. Any impacts on nutrient cycling extend well beyond the populations of these species. This is critical in systems where foundation species are also heavily harvested as NTFPs, such as Colophospermum mopane in the dry woodlands of southern Africa (Mlambo and Nyathi 2008), Phragmites australis reedbeds (Kiviat 2013) globally, or intertidal mussel beds in northeastern coastal USA (Bertnes 1984).

Nutrient provisioning services are not restricted to foundation species: in most systems certain species tend to spatially or temporally concentrate nutrients more than others. Many of these are also important NTFP species. We consider these in four groups, namely (i) animal excreta, (ii) animal carcasses, (iii) plant nutrient pumps, and (iv) animal-mediated soil turnover.

Animal excretions can provide nutrient-rich patches on which other species may come to depend, especially in nutrient-poor systems. Examples abound for vertebrates and invertebrates, which may also be NTFP species in some regions. Mammals such as rhinoceros, antelope, and viverrids maintain dung middens much of the year, resulting in small $\left(<20 \mathrm{~m}^{2}\right)$, nutrient-enriched patches that are later colonized by particular plant species (Tinley 1978, Shackleton 1992). The colonizing vegetation is typically nutrient-rich, and can eventually lead to persistent grazing lawns (Cromsigt and Olff 2008). Elevated nutrient levels may also influence soil biota and bacterial communities; for example, soils under nests of White-backed Vulture (Gyps africanus), an iconic cultural species also used for medicine, have almost five times higher phosphorous concentrations, twice as much nitrogen, and $14 \%$ more bacterial operational taxonomic units than control sites (Ganz et al. 2012; Table 1).

Animal carcasses also deposit spatially localized nutrients; for example, Pacific salmon (Oncorhynchus spp.) in riparian forests of Alaska are a cultural keystone species there, deeply embedded in many societies' identities, folklore, traditions, and culture (Noble et al. 2016). Salmon provide a number of services, e.g., food to multiple species and, during the spawning run, substantial contributions to nutrient budgets of local streams: up to $25 \%$ of the nitrogen budget in the riparian zone (Helfield and Naiman 2006), and the second highest nitrogen source after leaching (Table 1). 
Plant growth processes can also lead to spatially discrete nutrient enrichment. This is widely documented in large, isolated trees in savanna, grassland, shrubland, or semidesert systems. Such trees may be keystones for different services, including food, shelter (e.g., Acacia erioloba; Milton and Dean 1995), and cultural values (e.g., Ceiba pentandra and Boscia albitrunca; Alias et al. 2003). Many authors have reported higher soil nutrients under large tree canopies compared with soils between canopies (Belsky et al. 1993, Ludwig et al. 2004), and subcanopy environments typically have higher productivity and distinct understory species (Ludwig et al. 2004), a likely result of altered soil nutrient, moisture, light, and temperature regimes. These sites also attract herbivores seeking shade or fodder, which in turn may be hunted.

Deep soil nutrients can be brought to the surface by activity such as burrowing and building (Haussmann 2016). Both heavily hunted vertebrates, such as aardvarks in Africa (Haussmann 2016) or armadillos in the Americas (Sawyer et al. 2012), and invertebrates such as mound-building termites throughout subSaharan Africa and Amazonia (Anankware et al. 2014), are capable of zoogeomorphy. Termites in particular, as well as being important NTFP food species, are well known for creating longlived, nutrient- and clay-rich patches that become sites for colonization by particular suites of plant and fungal species. Nutrient-rich soils from termitaria are collected by humans for agricultural use, pottery, and medicine (Geissler 2000, van Huis 2017), while many bird and mammal species also ingest soil from termitaria (Limpitlaw 2010).

\section{Shelter and protection}

Across many ecosystems, NTFP species also provide a range of "nontrophic" services to other organisms. These include burrows and cavities, roosts and perches, hollow logs, phytotelmata, and protective "cages" of branches or spiny vegetation. Collectively these spatial resources can have such large-scale influences on biodiversity and habitat heterogeneity that Tews et al. (2004) introduced the term "keystone structures" to describe them. We discuss some of these below.

\section{Excavators}

There are comprehensive reviews of plants and animals as ecosystem engineers (Jones et al. 1994, Hastings et al. 2007), including animals with strong cultural associations as NTFPs. Porcupines, used widely for food, cultural practice, and traditional medicine, influence useful plant species at multiple spatial scales. Indian crested porcupines (Hystrix indica) foraging for geophytes in the Negev desert dig pits that collect moisture; that moisture triggers further geophyte regeneration (Gutterman 1987). In contrast, African porcupines (Hystrix africae-australis) combined with fire effects create more open savanna by eating Burkea africana bark (Yeaton 1988). Aardvark tunnels in Africa, created in foraging for termites, are important nesting habitat for endangered Blue Swallows (Hirundo atrocaerulea; Wakelin et al. 2013). Aaardvarks, used commercially for ritual purposes (Cunningham and Zondi 1991, Whiting et al. 2013), also are key dispersers of the world's only underground fruiting melon, Cucumis humifrutus (Hoffmann and Myburgh 1995).

Tree cavities and hollows

These can be natural cavities and hollows, or created by birds or animals. Across Australia, Europe, North America, and southern Africa, between 9-18\% of all bird species use tree cavities (Newton 1994a, b, Eadie et al. 1998). In general, low-density, softwood tree species are preferred by hole-nesting birds creating their own cavities. In the tropics, figs (Moraceae), marula (Anacardiaceae), and baobabs (Bombaceae), are large trees, keystone food resources for people and animals, and typically also have low-density wood that is easy to excavate, so they tend to serve as keystone sheltering structures. All of the hole-nesters (barbets, hoopoes, hornbills, woodpeckers) are commercially traded in Africa for traditional medicine (Williams et al. 2014).

\section{Perching and roosting trees}

Linkages between cultural keystone trees and culturally significant species that use them, such as bats and birds, occur widely and are well-known to local people. In African savannas, White-headed Vultures (Trigonoceps occipitalis) often nest in baobab trees (Mundy et al. 1992), as do a variety of eagles, all of which are culturally significant (Cunningham and Zondi 1991, Williams et al. 2014). Baobabs also provide nesting, roosting, and foraging sites for a wide range of other animals and microorganisms. Similarly in Amazonia, Peres (2000) suggested kapok (Ceiba pentandra) as keystone trees because their architecture and size provide a nontrophic service for a range of species, including Harpy Eagles (Harpia harpyja), that in turn influence populations of large arboreal mammals. The effects of removing roost trees are poorly studied.

\section{Phytotelmata}

These "plant ponds" are minihabitats formed in plant cavities such as leaf axils. They may support diverse species from vertebrates to microbes (Greeney 2001), typically with a positive relationship between plant size, water volume stored, and richness and abundance of associated fauna (Araújo et al. 2007). In tank bromeliads, individual plants are small but can occur at high densities, collectively serving as ecological keystones (Richardson 1999). Commercial trade in bromeliads has likely, but unstudied, negative consequences for biodiversity (Flores-Palacios and Valencia-Diaz 2007).

\section{Cultural symbolism}

The contribution of NTFPs to the culture of many user communities is well recognized (Posey 1999, Bennett 2002) and reported from both developed (Grabbatin et al. 2011, Kim et al. 2012) and developing world contexts, and rural (Lincoln and Orr 2011, Fadiman 2013) and urban (Cocks and Dold 2004, Grabbatin et al. 2011) settings. However, their role in cultural symbolism is far less explored, particularly in how communities and societies view selected NTFPs, which then influences their use and management. Belief that ritual potency is signaled by particular animals and plants is widespread in the worldviews, rituals, and religious beliefs of many cultural groups. Best known are the belief systems and symbolism linked to apex predators (lions, eagles, crocodiles), large mammals (elephants, rhinos, hippopotami), and large snakes (pythons, anacondas; Douglas 1957, 1970, Reichel-Dolmatoff 1996, Sullivan and Low 2014).

Certain bird species are also considered to have ritual potency. As Reichel-Dolmatoff (2005:111) eloquently points out, "birds fly, sing and dance and they have colourful plumage; they are therefore shamanic animals par excellence. Their keen sight, their claws, the diversity of their beaks, together with countless details of their specific behaviour associate them with the shamanic 
Fig. 3. Nontimber forest products (NTFPs) harvested directly from marula (Sclerocarya birrea subsp. caffra), their cultural significance, and other NTFPs preferentially found in or near marula trees.

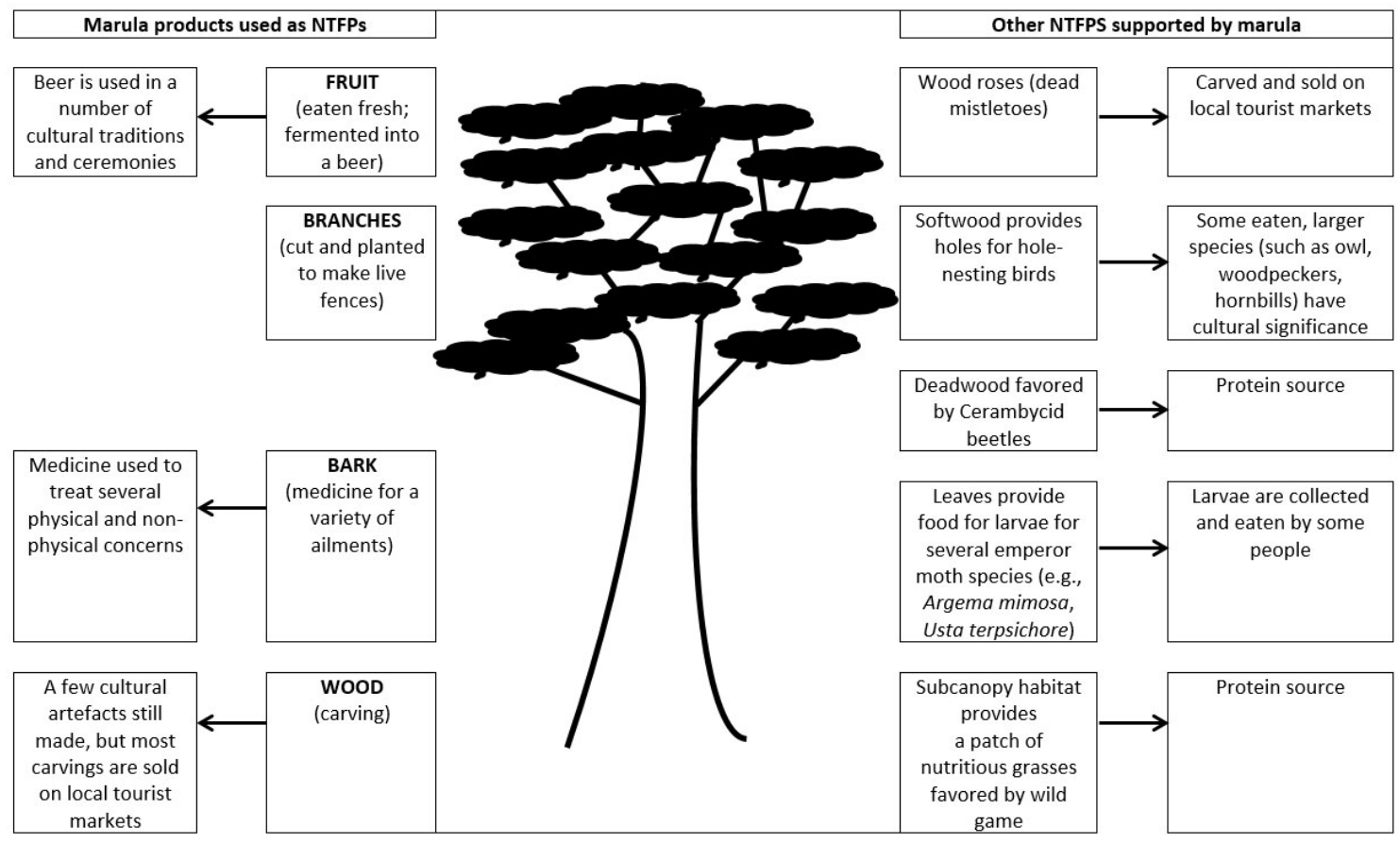

world more than any other group of animals; this can be observed in many parts of the world and in all periods." The quantities of birds targeted for their symbolism has been significant in the past. In the Santa Cruz Islands, for example, an estimated 20,000 Scarlet Honeyeaters (Myzomela cardinalis) were historically hunted for their red feathers to create currency rolls used in interisland trading (Houston 2010a). In New Zealand, Maori chiefs wore the black-and-white tail feathers from now extinct Huia (Heteralocha acutirostris) during special ceremonies or when going to war, with selection probably due to the symbolism of the tail-feather colors, the sexual dimorphism of the beaks, and the behavior of this species (Houston 2010b). Large-scale trade in culturally important birds continues today (Williams et al. 2014) especially hornbills, eagles, and vultures. This is particularly the case in Africa, where over 350 species are commercially traded for their symbolic potency (Williams et al. 2014). Although $24 \%$ of traded African bird species are very common and locally abundant in several habitats over a large geographic area, $10 \%$ of species are rare and occur in low numbers in specific habitats over a small geographic area, with the Bucerotiformes (hornbills) having the highest proportion of rare species.

Although Nuñez and Simberloff (2005) note that cultures and memories can change quite rapidly and that some cultural keystone species may no longer be regarded as such within a particular society, some beliefs are very resilient, including within urban areas (Grabbatin et al. 2011, Cocks et al. 2016, Short Gianotti and Hurley 2016). That persisting beliefs in ritual potency generate a thriving trade in animal species is one example of this (Alves and Lucena Rosa 2013, Williams et al. 2014).
Another is the continued use of body parts and skins from crocodiles, python, lions, and leopards by tribal and religious leaders across southern Africa (Cunningham and Zondi 1991, Salokoski 2006), following belief systems with deep historical roots (Huffman 1996); as well as the continued belief that traditional leaders and shamans can turn themselves into wild animals such as jaguars or lions (Salokoksi 2006, West 2007). The harvest of urban NTFPs to maintain traditional basketry in the southeastern USA reflects another resilient cultural practice (Grabbatin et al. 2011).

\section{SYNTHESIS}

From the wide-ranging consideration of the several different services provided by many different NTFP species that are ecological biocultural keystone species that we have presented above, it is possible to draw a number of core considerations. We present these in the following section.

\section{Many NTFPs play critical roles in supporting other species, cultures, and ecological communities}

The numerous examples that we have provided across all types of life forms, species, ecosystems, and continents demonstrate that many NTFPs provide a host of different services to the biological and cultural communities in which they are situated. We deliberately considered keystone species to emphasize the point that loss or reduction in NTFP species would have ramifications not only for the human users of those NTFPs, but ecological and cultural impacts as well. This hitherto underappreciated value of NTFPs needs to be more widely recognized and communicated amongst NTFP researchers, biodiversity product developers, conservationists, and policy analysts (Shackleton 2015). 
Table 2. Emerging research questions around nontimber forest products (NTFPs) as biocultural keystones.

\begin{tabular}{|c|c|}
\hline Research domain & Emerging research questions \\
\hline $\begin{array}{l}\text { Many NTFPs play critical roles in supporting other } \\
\text { species, cultures, and ecological communities. }\end{array}$ & $\begin{array}{l}\text { What types of services do NTFPs provide to other species and cultures?; } \\
\text { How widespread are they?; } \\
\text { How strong and substitutable are these services? }\end{array}$ \\
\hline Some NTFP keystones support other NTFPs. & $\begin{array}{l}\text { How common are dependencies between different NTFPs?; } \\
\text { Are the implications of such dependencies understood by NTFP and resource management } \\
\text { actors?; } \\
\text { What are the cultural and ecological implications as species populations change? }\end{array}$ \\
\hline $\begin{array}{l}\text { Individual keystone species can support a wide range } \\
\text { of dependencies. }\end{array}$ & $\begin{array}{l}\text { How multifunctional are biocultural keystones?; } \\
\text { Does multifunctionality foster greater probabilities of overuse?; } \\
\text { What management approaches will best support multifunctionality? }\end{array}$ \\
\hline Keystone species links are spatially variable. & $\begin{array}{l}\text { Why are the same or similar species not consistently keystones in different settings?; } \\
\text { What attributes of the SES underpin the likely presence of biocultural keystones?; } \\
\text { How does scale of analysis influence detection of biocultural keystones? }\end{array}$ \\
\hline $\begin{array}{l}\text { Lag effects can mask relationships and dependencies } \\
\text { and the consequences of their decline. }\end{array}$ & $\begin{array}{l}\text { What evidence is there of lag effects in different contexts?; } \\
\text { How can potential lag effects on ecological and cultural dynamics be predicted and modeled?; } \\
\text { How can recognition of potential lag effects be accommodated in governance and } \\
\text { management systems? }\end{array}$ \\
\hline $\begin{array}{l}\text { Many NTFPs serve as both ecological and cultural } \\
\text { keystones, or "biocultural" keystones, requiring } \\
\text { interdisciplinary enquiry and management. }\end{array}$ & $\begin{array}{l}\text { Are (nondomesticated) cultural keystone NTFPs more likely to be biological keystones than } \\
\text { other NTFPs?; } \\
\text { How can SES theory and praxis inform research on and management of biocultural } \\
\text { keystones?; } \\
\text { How can cultural values be incorporated into NTFP management and conservation } \\
\text { approaches? }\end{array}$ \\
\hline
\end{tabular}

\section{Some NTFP keystones support other NTFPs}

Although acknowledging the connections of NTFP keystones with other species and cultures is vital, a particular subset of interactions of primary interest to the NTFP sector are those between two or more NTFP species. For example, marula (Sclerocarya birrea), as described previously, is an ecological and cultural keystone (Hall et al. 2002, Shackleton et al. 2002). Additionally, several of the species it supports are also NTFPs (Fig. 3). First, it provides a source of food to many vertebrate and invertebrate species (Hall et al. 2002), which in turn are trapped as foods by local people. Second, it is the principal and preferred host of two mistletoe species (Erianthemum dregei and Pedistylis galpinii), both of which are harvested by local crafters (Dzerefos et al. 2003). Thus, loss of a keystone such as marula would not only have negative impacts on ecological and cultural connections, it would also diminish other species that directly contribute to local livelihoods. Another example is the value of many bird species, which may be hunted for food or rituals purposes, in turn serve to disperse the seeds of NTFP species that provide fruits, fibre, resins, or wood. These examples illustrate the potential cascade effects of reduced populations of NTFPs that are keystones.

\section{Individual keystone species can support a wide range of dependencies}

Much of the research on ecological keystone species is fragmented according to the subjectively identified primary service provided by the species under examination, or by the interests of the researcher. There are relatively few studies that have examined all the species-level interactions and dependencies (keystone or not) that a single keystone species potentially offers to co-occurring species and people. Yet it is evident from Table 1 that many species considered keystone for a particular function also provide additional services, some of which in turn may be keystone for co-occurring species or people. This is strongly evident for those keystones that support both ecological and cultural functions. But some keystones contribute meaningfully to most of the six services that we have considered. This requires that work on keystones needs to move from uni-functional to multifunctional if we hope to have clear determinations of their roles and relative importance. It may also allow identification of bundles of keystone services analogous to bundling of ecosystem goods and services (Raudsepp-Hearne et al. 2010), allowing identification of potential complementarities or trade-offs between services.

\section{Keystone species links are spatially variable}

Some of the case examples showed that the links and dependencies between certain keystone NTFPs are spatially variable. Thus, being a biocultural keystone in one place does not necessarily make them so in another. Understanding why this should be so is a matter for further investigation. The implications are that different sites will require their own context-specific information, and once there is a sufficiently large sample, a meta-analysis might lead to generalizable patterns or relationships.

\section{Lag effects can mask relationships and dependencies and the consequences of their decline}

Inferring, identifying, or revealing the strength and nature of links between biocultural keystones and other species is often painstaking work. Moreover, as indicated above, it is contextspecific, resulting in marked spatial variation. Removal experiments perhaps lead to the clearest conclusions, but present ethical problems when conducted at scale or with species already under threat. Additionally, in complex and biodiverse systems the results of removal of a suspected keystone, whether done deliberately or as a result of other processes, can take years or even decades to manifest if the dependent species are long lived. For example, removal of a keystone pollinator or disperser will 
not result in the immediate demise of tree populations that were dependent on the pollination or dispersal services, because there may be a seedbank that will continue to provide new recruits into the population for several decades. Additionally, it takes decades for single individuals of long-lived species to die and fade from the population. The implication here is that by the time the decline in a particular species is noticed, it may well be too late to halt or revert it. This is analogous to the extinction debt resulting from habitat fragmentation (Jackson and Sax 2010). The same can apply to cultural keystones, which may be retained in folklore and traditions even in the face of local or wider extirpation, or cultural shifts.

\section{Many NTFPs serve as both ecological and cultural keystones, or biocultural keystones, requiring interdisciplinary enquiry and management}

By their very nature, most research into and management of NTFPs requires both social and natural science skills and perspectives. The manifestation of some NTFPs simultaneously as both cultural and ecological keystones, or "biocultural" keystones, strengthens the need for interdisciplinary framings and approaches. Additionally, it projects such species as a robust embodiment of the links between social and ecological systems (Fig. 1), and demands that they enjoy focused and strong conservation and management. Indeed, their joint ecological and cultural values situate them as ideal foci for conservation initiatives (Noble et al. 2016).

\section{CONCLUSION}

We have drawn from a wide range of literature to build the argument that many NTFPs are keystone species: ecological, cultural, or biocultural. Consequently, assessment of the impacts of NTFP harvesting needs to move beyond just the organism and population levels (Ticktin 2004), or livelihood and economic consequences, to include dependencies and linkages in the broader SES (Shackleton 2015) and within the different domains of SES. Doing so could serve to minimize or limit declines of species or cultural practices dependent on NTFP keystones. Although we focus on NTFPs and the impacts of their harvesting by humans, we also recognize that larger scale impacts, e.g., fire, land use change, climate change, or invasive alien species, may be more significant drivers of change for many NTFP populations and their associated dependencies, than harvesting.

This realization provides the impetus for critical future work in situating NTFPs as biological keystones (Table 2). Foundational to all of these is further work on identifying which and what proportion of NTFP species serve as biocultural keystones, and how to use such knowledge in management and conservation approaches. This would facilitate the application of broader SES framings and theory in the management of NTFPs.

\section{Responses to this article can be read online at:} http://www.ecologyandsociety.org/issues/responses. $\mathrm{php} / 10469$

\section{Acknowledgments:}

This work was sponsored by the South African Research Chairs Initiative of the Department of Science and Technology and the National Research Foundation of South Africa. Any opinion, finding, conclusion or recommendation expressed in this material is that of the authors and the NRF does not accept any liability in this regard. We are grateful for comments on an earlier draft of this paper from Wayne Twine and Penny Mograbi.

\section{LITERATURE CITED}

Abera, B. 2014. Medicinal plants used in traditional medicine by Oromo people, Ghimbi District, southwest Ethiopia. Journal of Ethnobiology and Ethnomedicince 10(1):40. http://dx.doi. org/10.1186/1746-4269-10-40

Alaribe, C. S., F. Shode, H. A. Coker, G. Ayoola, A. Sunday, N. Singh, and S. Iwuanyanwu. 2011. Antimicrobial activities of hexane extract and decussatin from stembark extract of Ficus congensis. International Journal of Molecular Sciences 12:2750-2756. http://dx.doi.org/10.3390/ijms12042750

Alias, D., S. Milton, E. Herrmann, and C. Seymour. 2003. A collation and overview of research information on Boscia albitrunca (Shepherd's Tree) and identification of relevant research gaps to inform protection of the species. Department of Water Affairs \& Forestry, Pretoria, South Africa.

Alves, R. R. N., and I. Lucena Rosa, editors. 2013. Animals in traditional folk medicine. Springer-Verlag, Heidelberg, Germany. http://dx.doi.org/10.1007/978-3-642-29026-8

Anankware, P. J., K. O. Fening, E. Osekre, and D. Obeng-Ofori. 2014. Insects as food and feed: a review. International Journal of Agricultural Research \& Review 3:143-151.

Angelsen, A., P. Jagger, R. Babigumira, B. Belcher, N. J. Hogarth, S. Bauch, J. Börner, C. Smith-Hall, and S. Wunder 2014. Environmental income and rural livelihoods: a global comparative analysis. World Development 64(S1):S12-S28. http:// dx.doi.org/10.1016/j.worlddev.2014.03.006

Araújo, V. A., S. K., Melo, A. P. Araújo, M. L. Gomes, and M. A. Carneiro. 2007. Relationship between invertebrate fauna and bromeliad size. Brazilian Journal of Biology 67:611-617. http://dx. doi.org/10.1590/S1519-69842007000400004

Assogbadjo, A. E., R. Glèlè Kakaï, F. G. Vodouhê, C. A. Djagoun, J. T. Codjia, and B. Sinsin. 2012. Biodiversity and socioeconomic factors supporting farmers' choice of wild edible trees in the agroforestry systems of Benin (West Africa). Forest Policy and Economics 14:41-49. http://dx.doi.org/10.1016/j.forpol.2011.07.013

Belcher, B., M. Ruíz-Pérez, and R. Achdiawan. 2005. Global patterns and trends in the use and management of commercial NTFPs: implications for livelihoods and conservation. World Development 33:1435-1452. http://dx.doi.org/10.1016/j. worlddev.2004.10.007

Belsky A. J., S. M. Mwonga, R. G. Amundson, J. M. Duxbury, and A. R. Ali. 1993. Comparative effects of isolated trees on their undercanopy environments in high- and low-rainfall savannas. 
Journal of Applied Ecology 30:143-155. http://dx.doi. org/10.2307/2404278

Bennett, B. C. 2002. Forest products and traditional peoples: economic, biological and cultural considerations. Natural Resources Forum 26:293-301. http://dx.doi.org/10.1111/1477-8947.00032

Bennett, E. L., A. J. Nyaoi, and J. Sompud. 1997. Hornbills Buceros spp. and culture in northern Borneo: Can they continue to co-exist? Biological Conservation 82:41-46. http://dx.doi. org/10.1016/S0006-3207(97)00012-8

Bernal, R. 1998. Demography of the vegetable ivory palm Phytelephas seemannii in Colombia, and the impact of seed harvesting. Journal of Applied Ecology 35:64-74. http://dx.doi. org/10.1046/j.1365-2664.1998.00280.x

Bertnes, M. D. 1984. Ribbed mussels and Spartina alterniflora production in a New England salt marsh. Ecology 65:1794-1807. http://dx.doi.org/10.2307/1937776

Bodmer, R. E. 1991. Strategies of seed dispersal and seed predation in Amazonian ungulates. Biotropica 23:255-261. http:// dx.doi.org/10.2307/2388202

Bonta, M., O. F. Pinot, D. Graham, J. Haynes, and G. Sandoval. 2006. Ethnobotany and conservation of Tuisinte (Dioon mejiae Standl. \& L.O. Williams, Zamiaceae) in northeastern Honduras. Journal of Ethnobiology 26:228-257. http://dx.doi.org/10.2993/0278-0771 (2006)26[228:EACOTD]2.0.CO;2

Butchart, S. H. M. 2008. Red List Indices to measure the sustainability of species use and impacts of invasive alien species. Bird Conservation International 18(S1):S245-S262. http://dx.doi. org/10.1017/S095927090800035X

Butler, J. R. A., A. Tawake, T. Skewes, L. Tawake, and V. McGrath. 2012. Integrating traditional ecological knowledge and fisheries management in the Torres Strait, Australia: the catalytic role of turtles and dugong as cultural keystone species. Ecology and Society 17(4):34. http://dx.doi.org/10.5751/ES-05165-170434

Cardillo, M., G. M. Mace, K. E. Jones, J. Bielby, O. R. BinindaEmonds, W. Sechrest, C. D. L. Orme, and A. Purvis. 2005. Multiple causes of high extinction risk in large mammal species. Science 309(5738):1239-1241. http://dx.doi.org/10.1126/science.1116030

Caro, T. 2010. Conservation by proxy: indicator, umbrella, keystone, flagship, and other surrogate species. Island Press, Washington, D.C., USA.

Caughlin, T. T., T. Ganesh, and M. D. Lowman. 2012. Sacred fig trees promote frugivore visitation and tree seedling abundance in South India. Current Science 102:918-922.

Chapman, C. A., L. J. Chapman, K. D. Rode, E. M. Hauckand, and L. R. McDowell. 2003. Variation in the nutritional value of primate foods: among trees, time periods, and areas. International Journal of Primatology 24:317-333. http://dx.doi.org/10.1023/ A:1023049200150

Cocks, M., J. Alexander, L. Mogano, and S. Vetter. 2016. Ways of belonging: meanings of "nature" among Xhosa-speaking township residents in South Africa. Journal of Ethnobiology 36:820-841. http://dx.doi.org/10.2993/0278-0771-36.4.820
Cocks, M. L., and A. P. Dold. 2004. A new broom sweeps clean: the economic and cultural value of grass brooms in the Eastern Cape province, South Africa. Forests, Trees and Livelihoods 14:33-42. http://dx.doi.org/10.1080/14728028.2004.9752477

Colwell, R. K., R. R. Dunn, and N. C. Harris. 2012. Coexistence and persistence of dependent species in a changing world. Annual Review of Ecology, Evolution \& Systematics 43:183-203. http://dx. doi.org/10.1146/annurev-ecolsys-110411-160304

Coomes, O. T., Y. Takasaki, C. Abizaid, and J. P. Arroyo-Mora. 2016. Environmental and market determinants of economic orientation among rain forest communities: evidence from a largescale survey in western Amazonia. Ecological Economics 129:260-271. http://dx.doi.org/10.1016/j.ecolecon.2016.06.001

Cottee-Jones, H. E., and R. J. Whittaker. 2012. The keystone species concept: a critical appraisal. Frontiers of Biogeography 4:117-127. http://dx.doi.org/10.21425/F54312533

Cristancho, S., and J. Vining. 2004. Culturally defined keystone species. Human Ecology Review 11:153-164.

Cromsigt, J. P., and H. Olff. 2008. Dynamics of grazing lawn formation: an experimental test of the role of scale-dependent processes. Oikos 117:144-1452. http://dx.doi.org/10.1111/ j.0030-1299.2008.16651.x

Cunningham, A. B. 1985. The resource value of indigenous plants to rural people in a low agricultural potential area. Dissertation. University of Cape Town, Cape Town, South Africa.

Cunningham, A. B. 2015. Trade study of selected East African timber production species (Handelsstudie zu ostafrikanischen Holzarten). Federal Agency for Nature Conservation, Bonn, Germany. [online] URL: https://cites.org/sites/default/files/eng/ cop/17/InfDocs/E-CoP17-Inf-47.pdf

Cunningham, A., V. F. Anoncho, and T. Sunderland. 2016. Power, policy and the Prunus africana bark trade, 1972-2015. Journal of Ethnopharmacology 178:323-333. http://dx.doi.org/10.1016/j. jep.2015.11.042

Cunningham, A. B., B. Belcher, and B. M. Campbell, editors. 2005. Carving out a future: tropical forests, livelihoods and the international woodcarving trade. Earthscan, London, UK.

Cunningham. A., and F. T. Mbenkum. 1993. Sustainability of harvesting Prunus africana bark in Cameroon - a medicinal plant in international trade. WWF/UNESCO/Kew People and Plants Working paper no 2. UNESCO, Paris, France.

Cunningham, A. B., and A. S Zondi. 1991. Use of animal parts for the commercial trade in traditional medicines. Institute of Natural Resources, Pietermaritzburg, South Africa.

Davidar, P., K. Yoganand, and T. Ganesh. 2001. Distribution of forest birds in the Andaman islands: importance of key habitats. Journal of Biogeography 28:663-671. http://dx.doi.org/10.1046/ j.1365-2699.2001.00584.X

de Castro Ishida, V. F., G. Negri, A. Salatino, and M. F. Bandeira. 2011. A new type of Brazilian propolis: Prenylated benzophenones in propolis from Amazon and effects against cariogenic bacteria. Food Chemistry 125:966-972. http://dx.doi. org/10.1016/j.foodchem.2010.09.089 
Deachathai, S., W. Mahabusarakam, S. Phongpaichit, and W. C. Taylor. 2005. Phenolic compounds from the fruit of Garcinia dulcis. Phytochemistry 66:2368-2375. http://dx.doi.org/10.1016/j. phytochem.2005.06.025

Douglas, M. 1957. Animals in Lele religious symbolism. Africa 27:46-58. http://dx.doi.org/10.2307/1156365

Douglas, M. 1970. Natural symbols: explorations in cosmology. Barrie \& Rockliff, London, UK.

Dzerefos, C. M., E. T. Witkowski, and C. M. Shackleton. 2003. Host preference and density of woodrose-forming mistletoes (Loranthaceae) on savanna vegetation, South Africa. Plant Ecology 167:163-177. http://dx.doi.org/10.1023/A:1023991514968

Eadie, J. M., P. Sherman, and B. Semel. 1998. Conspecific brood parasitism, population dynamics, and the conservation of cavitynesting birds. Pages 306-340 in T. Caro, editor. Behavioral ecology and conservation biology. Oxford University Press, Oxford, UK.

Eiserhardt, W. L., J.-C. Svenning, W. D. Kissling, and H. Balslev. 2011. Geographical ecology of the palms (Arecaceae): determinants of diversity and distributions across spatial scales. Annals of Botany 108:1391-1416. http://dx.doi.org/10.1093/aob/ $\underline{\operatorname{mcr} 146}$

Endress, B. A., D. L. Gorchov, and E. J. Berry. 2006. Sustainability of a non-timber forest product: effects of alternative leaf harvest practices over 6 years on yield and demography of the palm Chamaedorea radicalis. Forest Ecology \& Management 234:181-191. http://dx.doi.org/10.1016/j.foreco.2006.07.020

Fadiman, M. 2013. Marketing, culture and conservation value of NTFPs: the case of Afro-Ecuadorian use of piquigua, Heteropsis ecuadorensis (Araceae). Pages 175-194 in R. Voeks and J. Rashford, editors. African ethnobotany in the Americas. Springer, New York, New York, USA. http://dx.doi.org/10.1007/978-1-4614-0836-9 7

Fashing, P. J. 2004. Mortality trends in the African cherry (Prunus africana) and the implications for colobus monkeys (Colobus guereza) in Kakamega Forest, Kenya. Biological Conservation 120:449-459. http://dx.doi.org/10.1016/j.biocon.2004.03.018

Flores-Palacios, A., and S. Valencia-Diaz. 2007. Local illegal trade reveals unknown diversity and involves a high species richness of wild vascular epiphytes. Biological Conservation 136:372-387. http://dx.doi.org/10.1016/j.biocon.2006.12.017

Forget, P. M., and P. A. Jansen. 2007. Hunting increases dispersal limitation in the tree Carapa procera, a nontimber forest product. Conservation Biology 21:106-113. http://dx.doi.org/10.1111/ j.1523-1739.2006.00590.x

Galetti, M., and A. Aleixo. 1998. Effects of palm heart harvesting on avian frugivores in the Atlantic rain forest of Brazil. Journal of Applied Ecology 35:286-293. http://dx.doi.org/10.1046/ j.1365-2664.1998.00294.x

Gallai, N., J. M. Salles, J. Settele, and B. E. Vaissière. 2009. Economic valuation of the vulnerability of world agriculture confronted with pollinator decline. Ecological Economics 68:810-821. http://dx.doi.org/10.1016/j.ecolecon.2008.06.014
Ganz, H. H., U. Karaoz, W. M. Getz, W. Versfeld, and E. J. Brodie. 2012. Diversity and structure of soil bacterial communities associated with vultures in an African savanna. Ecosphere 3:1-18. http://dx.doi.org/10.1890/ES11-00333.1

Garibaldi, A. 2009. Moving from model to application: cultural keystone species and reclamation in Fort McKay, Alberta. Journal of Ethnobiology 29:323-338. http://dx.doi.org/10.2993/0278-0771-29.2.323

Garibaldi, A., and N. Turner. 2004. Cultural keystone species: implications for ecological conservation and restoration. Ecology and Society 9(3):1. http://dx.doi.org/10.5751/ES-00669-090301

Geissler, P. W. 2000. The significance of earth-eating: social and cultural aspects of geophagy among Luo children. Africa 70:653-682. http://dx.doi.org/10.3366/afr.2000.70.4.653

Ghimire, S. K., O. Gimenez, R. Pradel, D. McKey, and Y. Aumeeruddy-Thomas. 2008. Demographic variation and population viability in a threatened Himalayan medicinal and aromatic herb Nardostachys grandiflora: matrix modelling of harvesting effects in two contrasting habitats. Journal of Applied Ecology 45:41-51. http://dx.doi.org/10.1111/j.1365-2664.2007.01375. $\mathrm{x}$

Gilmore, M. P., B. A. Endress, and C. M. Horn. C. 2013. The socio-cultural importance of Mauritia flexuosa palm swamps (aguajales) and implications for multi-use management in two Maijuna communities of the Peruvian Amazon. Journal of Ethnobiology \& Ethnomedicine 9:29. http://dx.doi. org/10.1186/1746-4269-9-29

Grabbatin, B., P. T. Hurley, and A. Halfacre. 2011. "I still have the old tradition": the coproduction of sweetgrass basketry and coastal development. Geoforum 42:638-649. http://dx.doi. org/10.1016/j.geoforum.2011.06.007

Greeney, H. F. 2001. The insects of plant-held waters: a review and bibliography. Journal of Tropical Ecology 17:241-260. http:// dx.doi.org/10.1017/S026646740100116X

Gutterman, Y. 1987. Dynamics of porcupine (Hystrix indica Kerr) diggings: their role in the survival and renewal of geophytes and hemicryptophytes in the Negev Desert highlands. Israel Journal of Botany 36:133-143.

Hall, J. B., E. M. O'Brien, and F. L. Sinclair. 2002. Sclerocarya birrea: a monograph. Publication no. 19, School of Agricultrural and Forest Sciences, University of Wales, Bangor, Wales.

Hastings, A., J. E. Byers, J. A. Crooks, K. Cuddington, C. G. Jones, J. G. Lambrinos, and W. G. Wilson. 2007. Ecosystem engineering in space and time. Ecology Letters 10:153-164. http:// dx.doi.org/10.1111/j.1461-0248.2006.00997.x

Haussmann, N. S. 2016. Soil movement by burrowing mammals: a review comparing excavation size and rate to body mass of excavators. Progress in Physical Geography: Earth and Environment 41:29-45. http://dx.doi.org/10.1177/0309133316662569

Helfield, J. M., and R. J. Naiman. 2006. Keystone interactions: salmon and bear in riparian forests of Alaska. Ecosystems 9:167-180. http://dx.doi.org/10.1007/s10021-004-0063-5

Hladik, A., E. G., Leigh, and F. Bourliere. 1993. Food production and nutritional value of wild and semi-domesticated species- 
background. Pages 127-138 in C. M. Hladik, A. Hladik, O. F. Linarea, H. Pagezy, A. Semple, and M. Hadley, editors. Tropical forest, people, and food. Parthenon, Paris, France.

Ho, P.-H. 1999. An illustrated flora of Vietnam. Nha Xuat Ban Tre, Ho Chi Minh City, Vietnam.

Hoffmann, B., and J. Myburgh. 1995. Aardvark and cucumber: a remarkable relationship. Veld \& Flora 81(4):108.

Houston, D. C. 2010a. The impact of red feather currency on the population of the scarlet honeyeater on Santa Cruz. Pages 55-66 in S. Tidemannand A. Gosler, editors. Ethno-ornithology: birds, indigenous peoples, culture and society. Earthscan, London, UK.

Houston, D. C. 2010b. The Maori and the Huia. Pages 49-54 in S. Tidemannand A. Gosler, editors. Ethno-ornithology: birds, indigenous peoples, culture and society. Earthscan, London, UK.

Huffman, T. N. 1996. Snakes and crocodiles: power and symbolism in ancient Zimbabwe. Witwatersrand University Press, Johannesburg, South Africa.

Hurley, P., and M. R. Emery. 2018. Locating provisioning ecosystem services in urban forests: forageable woody species in New York City, USA. Landscape and Urban Planning 170:266-275. http://dx.doi.org/10.1016/j.landurbplan.2017.09.025

International Union for Conservation of Nature (IUCN). 2014. The redlist of threatened species: Pteropus. IUCN Global Species Programme Red List Unit, Cambridge, UK. [online] URL: https://www.iucnredlist.org/search?query=Pteropus\&searchType= species

Jackson, S. T., and D. F. Sax. 2010. Balancing biodiversity in a changing environment: extinction debt, immigration credit and species turnover. Trends in Ecology \& Evolution 25:153-160. http:// dx.doi.org/10.1016/j.tree.2009.10.001

Johns, T. 1990. With bitter herbs they shall eat it. University of Arizona Press, Tucson, Arizona, USA.

Jones, C. G., J. H. Lawton, and M. Shachak. 1994. Organisms as ecosystem engineers. Oikos 69:373-386. https://www.jstor.org/ stable/3545850

Kar, S. P., and M. G. Jacobson. 2012. NTFP income contribution to household economy and related socio-economic factors: lessons from Bangladesh. Forest Policy \& Economics 14:136-142. http://dx.doi.org/10.1016/j.forpol.2011.08.003

Kassa, G., and E. Yigezu. 2015. Women economic empowerment through non timber forest products in Gimbo District, south west Ethiopia. American Journal of Agriculture \& Forestry 3:99-104. http://dx.doi.org/10.11648/j.ajaf.20150303.16

Khan, T., I. A. Khan, A. Rehman, S. Ali, and H. Ali. 2014. Zoopharmacognosy and epigenetic behavior of mountain wildlife towards Berberis species. Life Science Journal 11:259-263.

Kim, I.-A., R. L. Trosper, and G. Mohs. 2012. Cultural uses of non-timber forest products among the Sts'ailes, British Colombia, Canada. Forest Policy and Economics 22:40-46. http://dx.doi. org/10.1016/j.forpol.2012.01.004

Kitamura, S. 2011. Frugivory and seed dispersal by hornbills (Bucerotidae) in tropical forests. Acta Oecologica 37:531-541. http://dx.doi.org/10.1016/j.actao.2011.01.015
Kiviat, E. 2013. Ecosystem services of Phragmites in North America with emphasis on habitat functions. AoB Plants 5:plt008. http://dx.doi.org/10.1093/aobpla/plt008

Koh, L. P., N. S. Sodhi, and B. Brook. 2004. Co-extinctions of tropical butterflies and their host plants. Biotropica 36:272-274.

Kurten, E. L. 2013. Cascading effects of contemporaneous defaunation on tropical forest communities. Biological Conservation 163:22-32. http://dx.doi.org/10.1016/j.biocon.2013.04.025

Limpitlaw, U. G. 2010. Ingestion of earth materials for health by humans and animals. International Geology Review 52:726-744. http://dx.doi.org/10.1080/00206811003679695

Lincoln, K., and B. Orr 2011. The use and cultural significance of the Pita plant (Aechmea magdalenae) among the Ngöbe women of Chalite, Panama. Economic Botany 65:13-26. http://dx.doi. org/10.1007/s12231-010-9144-X

Lokvam, J. 2000. Chemo-ecological and evolutionary aspects of the pollinator reward system in Clusia grandiflora (Clusiaceae). Dissertation. University of Alaska, Fairbanks, Alaska, USA.

Ludwig, F., H. de Kroon, F. Berendse, and H. H. T. Prins. 2004. The influence of savanna trees on nutrient, water and light availability and the understorey vegetation. Plant Ecology 170:93-105. http://dx.doi.org/10.1023/B:VEGE.0000019023.29636.92

Mandle, L., and T. Ticktin. 2012. Interactions among fire, grazing, harvest and abiotic conditions shape palm demographic responses to disturbance. Journal of Ecology 100:997-1008. http:// dx.doi.org/10.1111/j.1365-2745.2012.01982.x

Manning, A. D., J. Fischer, and D. B. Lindenmeyer. 2006. Scattered trees are keystone structures: implications for conservation. Biological Conservation 132:311-321. http://dx.doi. org/10.1016/j.biocon.2006.04.023

Mathabe, M. C., A. A. Hussein, R. V. Nikolova, A. E. Basson, J. J. M. Meyer, and N. Lall. 2008. Antibacterial activities and cytotoxicity of terpenoids isolated from Spirostachys africana. Journal of Ethnopharmacology 116:194-197. http://dx.doi. org/10.1016/j.jep.2007.11.017

McConkey, K. R., and D. R. Drake 2015. Low redundancy in seed dispersal within an island frugivore community. AoB Plants 7:plv088. http://dx.doi.org/10.1093/aobpla/plv088

McGinnis, M. D., and E. Ostrom. 2014. Social-ecological system framework: initial changes and continuing challenges. Ecology and Society 19(2):30. http://dx.doi.org/10.5751/ES-06387-190230

Mguni, S. 2006. King's monuments: identifying 'formlings' in southern African San rock paintings. Antiquity 80:583-598 http:// dx.doi.org/10.1017/S0003598X00094059

Mickleburgh, S., K. Waylen, and P. A. Racey. 2009. Bats as bushmeat: a global review. Oryx 43:217-234. http://dx.doi. org/10.1017/S0030605308000938

Milner-Gulland, E. J., and E. L. Bennett. 2003. Wild meat: the bigger picture. Trends in Ecology \& Evolution 18:351-357. http:// dx.doi.org/10.1016/S0169-5347(03)00123-X

Milton, S. J., and W. R. Dean. 1995. How useful if the keystone species concept and can it be applied to Acacia erioloba in the 
Kalahari Desert? Zeitschrift fur Okologie und Naturschutz 4:147-156.

Mlambo, D., and P. Nyathi. 2008. Litterfall and nutrient return in a semi-arid southern African savanna woodland dominated by Colophospermum mopane. Plant Ecology 196:101-110. http://dx. doi.org/10.1007/s11258-007-9337-2

Moegenburg, S. M., and D. J. Levey. 2003. Do frugivores respond to fruit harvest? An experimental study of short-term responses. Ecology 84:2600-2612. http://dx.doi.org/10.1890/02-0063

Mouquet, N., D. Gravel, F. Massol, and V. Calcagno. 2012. Extending the concept of keystone species to communities and ecosystems. Ecology Letters 16:1-8. http://dx.doi.org/10.1111/ ele. 12014

Mundy, P., D. Butchart, J. Ledger, and S. Piper. 1992. The vultures of Africa. Acorn Books, Randburg, South Africa.

Naniwadekar, R., C. Mishra, K. Isvaran, M. D. Madhusudan, and A. Datta. 2015. Looking beyond parks: the conservation value of unprotected areas for hornbills in Arunachal Pradesh, Eastern Himalaya. Oryx 49:303-311. http://dx.doi.org/10.1017/ $\underline{\mathrm{S} 0030605313000781}$

Newton, I. 1994a. Experiments on the limitation of bird breeding densities. Ibis 136:397-411. http://dx.doi.org/10.1111/j.1474-919X.1994. tb01115.x

Newton, I. 1994b. The role of nest sites in limiting the numbers of hole-nesting birds: a review. Biological Conservation 70:265-276. http://dx.doi.org/10.1016/0006-3207(94)90172-4

Noble, M., P. Duncan, D. Perry, K. Prosper, D. Rose, S. Schnierer, G. Tipa, E. Williams, R. Woods, and J. Pittock. 2016. Culturally significant fisheries: keystones for management of freshwater social-ecological systems. Ecology and Society 21(2):22. http://dx. doi.org/10.5751/ES-08353-210222

Nuñez, M. A., and D. Simberloff. 2005. Invasive species and the cultural keystone species concept. Ecology and Society 10(1):r4. http://dx.doi.org/10.5751/ES-01342-1001r04

Orwig, D. A., A. A. Plotkin, E. A. Davidson, H. Lux, K. E. Savage, and A. M. Ellison. 2013. Foundation species loss affects vegetation structure more than ecosystem function in a northeastern USA forest. PeerJ 1:e41. http://dx.doi.org/10.7717/ peerj.41

Paine, R. T. 1969. A note on trophic complexity and community stability. American Naturalist 103:91-93. http://dx.doi.org/10.1086/282586

Peres, C. A. 2000. Identifying keystone plant resources in tropical forests: the case of gums from Parkia pods. Journal of Tropical Ecology 16:287-317. http://dx.doi.org/10.1017/S0266467400001413

Peres, C. A., and E. Palacios. 2007. Basin-wide effects of game harvest on vertebrate population densities in Amazonian forests: implications for animal-mediated seed dispersal. Biotropica 39:304-315. http://dx.doi.org/10.1111/j.1744-7429.2007.00272.x

Plowden, C. 2004. The ecology and harvest of andiroba seeds for oil production in the Brazilian Amazon. Conservation \& Society 2(2):251.

Poe, M. R., K. C. Norman, and P. S. Levin. 2014. Cultural dimensions of socioecological systems: key connections and guiding principles for conservation in coastal environments Conservation Letters 7:166-175. http://dx.doi.org/10.1111/ $\underline{\text { conl.12068 }}$

Posey, D. 1999. Cultural and spiritual values of biodiversity: a complementary contribution to the global biodiversity assessment. Intermediate Technology Publications, London, UK., and United Nations Environment Programme, Nairobi, Kenya. http://dx.doi.org/10.3362/9781780445434

Posey, D. 2002. Kayapo ethnoecology and culture. Routledge, New York, New York, USA.

Potts, S. G., J. C. Biesmeijer, C. Kremen, P. Neumann, O. Schweiger, and W. E. Kunin. 2010. Global pollinator declines: trends, impacts and drivers. Trends in Ecology \& Evolution 25:345-353. http://dx.doi.org/10.1016/j.tree.2010.01.007

Power, M. E., and L. S. Mills. 1995. Keystone cops meet in Hilo. Trends in Ecology \& Evolution 10:182-184. http://dx.doi. org/10.1016/S0169-5347(00)89047-3

Power, M. E., D. Tilman, J. A. Estes, B. A. Menge, W. J. Bond, L. S. Mills, G. Daily, J. C. Castilla, J. Lubchenco, and R. T. Paine. 1996. Challenges in the quest for keystones. BioScience 46:609-620. http://dx.doi.org/10.2307/1312990

Prasad, S., and R. Sukumar. 2010. Context-dependency of a complex fruit-frugivore mutualism: temporal variation in crop size and neighborhood effects. Oikos 119:514-523. http://dx.doi. org/10.1111/j.1600-0706.2009.17971.x

Raudsepp-Hearne, C., G. D. Petersen, and E. M. Bennett. 2010. Ecosystem service bundles for analysing tradeoffs in diverse landscapes. Proceedings of the National Academy of Science 107:5242-5247. http://dx.doi.org/10.1073/pnas.0907284107

Reichel-Dolmatoff, G. 1996. The forest within the world-view of the Tukano Amazonian Indians. Council Oak Distribution, San Francisco, California, USA.

Reichel-Dolmatoff, G. 2005. Goldwork and shamanism: an iconographic study of the Gold Museum of the Banco de la República, Colombia. Villegas Asociados, Colombia.

Richardson, B. A. 1999. The bromeliad microcosm and the assessment of faunal diversity in a neotropical forest. Biotropica 31:321-336. http://dx.doi.org/10.1111/j.1744-7429.1999.tb00144. $\underline{\mathrm{X}}$

Salokoski, M. 2006. How kings are made, how kingship changes: a study of ritual and ritual change in pre-colonial Owamboland, Namibia. Research Series in Anthropology, University of Helsinki, Helsinki, Finland.

Sampaio, M. B., and F. A. M. dos Santos. 2015. Harvesting of palm fruits can be ecologically sustainable. Pages 73-89 in C. M. Shackleton, A. Pandey, and T. Ticktin, editors. Ecological sustainability for non-timber forest products: dynamics and case studies of harvesting. Routledge, New York, New York, USA.

Sanpa, S., M. Popova, V. Bankova, T. Tunkasiri, S. Eitssayeam, and P. Chantawannakul. 2015. Antibacterial compounds from propolis of Tetragonula laeviceps and Tetrigona melanoleuca (Hymenoptera: Apidae) from Thailand. PLoS ONE 10(5): e0126886 http://dx.doi.org/10.1371/journal.pone.0126886 
Sawyer, C. F., D. C. Brinkman, V. D. Walker, T. D. Covington, and E. A. Stienstraw. 2012. The zoogeomorphic characteristics of burrows and burrowing by nine-banded armadillos (Dasypus novemcinctus). Geomorphology 157-158:122-130. http://dx.doi. org/10.1016/j.geomorph.2012.01.028

Scanlon, A. T., S. Petit, M. Tuiwawa, and A. Naikatini. 2014. High similarity between a bat-serviced plant assemblage and that used by humans. Biological Conservation 174:111-119. http://dx. doi.org/10.1016/j.biocon.2014.03.023

Schlesinger, J., A. Drescher, and C. M. Shackleton. 2015. Sociospatial dynamics in the use of wild natural resources: evidence from six rapidly growing medium-sized cities in Africa. Applied Geography 56:107-115. http://dx.doi.org/10.1016/j.apgeog.2014.11.013

Shackleton, C. M. 1992. Area and species selection by wild ungulates in coastal sour grasslands of Mkambati Game Reserve, Transkei. African Journal of Ecology 30:189-202. http://dx.doi. org/10.1111/j.1365-2028.1992.tb00494.X

Shackleton, C. M. 2015. Non-timber forest products in livelihoods. Pages 12-30 in C. M. Shackleton, A. K. Pandey, and T. Ticktin, editors. The ecological sustainability for non-timber forest products: dynamics and case studies of harvesting. Earthscan, London, UK. http://dx.doi.org/10.4324/9781315851587

Shackleton, C. M., C. O. Delang, S. Shackleton, and P. Shanley. 2011. Non-timber forest products: concept and definition. Pages 3-21 in S. Shackleton, C. Shackleton, and P. Shanley, editors. Nontimber forest products in the global context. Springer, Heidelberg, Germany. http://dx.doi.org/10.1007/978-3-642-17983-9 1

Shackleton, C. M., P. T. Hurley, A. C. Dahlberg, M. R. Emery, and H. Nagendra. 2017. Urban foraging: a ubiquitous human practice but overlooked by urban planners, policy and research. Sustainability 9(10):1884. http://dx.doi.org/10.3390/su9101884

Shackleton, S. E., C. M. Shackleton, T. Cunningham, C. Lombard, C. A. Sullivan, and T. R. Netshiluvhi. 2002. Knowledge on Sclerocarya birrea subsp. caffra with emphasis on its importance as a non-timber forest product in South and southern Africa: A summary. Part 1: Taxonomy, ecology and role in rural livelihoods. Southern African Forestry Journal 194:27-41. http:// dx.doi.org/10.1080/20702620.2002.10434589

Short Gianotti, A. G., and P. T. Hurley. 2016. Gathering plants and fungi along the urban-rural gradient: uncovering differences in the attitudes and practices among urban, suburban, and rural landowners. Land Use Policy 57:555-563. http://dx.doi. org/10.1016/j.landusepol.2016.06.019

Sinasson, G. K. S., C. M. Shackleton, R. L. Glèlè Kakaï, and B. Sinsin. 2017. Forest degradation and invasive species synergistically impact Mimusops andongensis (Sapotaceae) in Lama Forest Reserve, Benin. Biotropica 49:160-169. http://dx.doi. org/10.1111/btp. 12370

Snyder, N. F., J. W. Wiley, and C. B. Kepler. 1987. The parrots of Luquillo: natural history and conservation of the Puerto Rican Parrot. Western Foundation of Vertebrate Zoology, Los Angeles, California, USA.

Stevenson, P. R. 2005. Potential keystone plant species for the frugivore community at Tinigua Park, Colombia. Pages 37-57 in
J. L. Dew and J. P. Boubli, editors. Tropical fruits and frugivores: the search for strong interactors. Springer, Heidelberg, Germany. http://dx.doi.org/10.1007/1-4020-3833-X 3

Stoner, K. E., K. Vulinec, S. J. Wright, and C. A. Peres. 2007. Hunting and plant community dynamics in tropical forests: a synthesis and future directions. Biotropica 39:385-392. http://dx. doi.org/10.1111/j.1744-7429.2007.00291.x

Sullivan, S., and C. Low. 2014. Shades of the rainbow serpent? A KhoeSan animal between myth and landscape in Southern Africa: ethnographic contextualisations of rock art representations. Arts 3:215-244. http://dx.doi.org/10.3390/arts3020215

Terborgh, J. 1986. Keystone plant resources in the tropical forest. Pages 330-344 in I. Soulé and E. Michael, editors. Conservation Biology. Sinauer, Sunderland, UK.

Tews, J., U. Brose, V. Grimm, K. Tielborger, M. C. Wichmann, M. Schwager, and F. Jeltsch. 2004. Animal species diversity driven by habitat heterogeneity/diversity: the importance of keystone structures. Journal of Biogeography 31:79-92 http://dx.doi. org/10.1046/j.0305-0270.2003.00994.x

Ticktin, T. 2004. The ecological implications of harvesting nontimber forest products. Journal of Applied Ecology 41:11-21. http://dx.doi.org/10.1111/j.1365-2664.2004.00859.x

Ticktin, T. 2015. The ecological sustainability of harvesting nontimber forest products: principles and methods. Pages 31-52 in C. Shackleton, A. Pandey, and T. Ticktin, editors. Ecological sustainability of non-timber forest product harvesting: case-studies and dynamics. Earthscan, London, UK.

Ticktin, T., R. Ganesan, M. Paramesha, and S. Setty. 2012. Disentangling the effects of multiple anthropogenic drivers on the decline of two tropical dry forest trees. Journal of Applied Ecology 49:774-784. http://dx.doi.org/10.1111/j.1365-2664.2012.02156. $\underline{x}$

Ticktin, T., R. Ganesan, M. Paramesha, and S. Setty. 2014. Disentangling, again, the drivers of population decline for two harvested species: a response to Prasad et al. Journal of Applied Ecology 51:648-654. http://dx.doi.org/10.1111/1365-2664.12249

Tinley, K. L. 1978. Framework of the Gorongosa ecosystem. Dissertation, University of Pretoria, Pretoria, South Africa.

Valls, A., M. Coll, and V. Christensen. 2015. Keystone species: toward an operational concept for marine biodiversity conservation. Ecological Monographs 85:29-47. http://dx.doi. org/10.1890/14-0306.1

Van Huis, A. 2017. Cultural significance of termites in subSaharan Africa. Journal of Ethnobiology and Ethnomedicine 13:8. http://dx.doi.org/10.1186/s13002-017-0137-z

Venter, S. M., and E. T. F. Witkowski. 2011. Baobab (Adansonia digitata L.) fruit production in communal and conservation landuse types in Southern Africa. Forest Ecology \& Management 261:630-639. http://dx.doi.org/10.1016/j.foreco.2010.11.017

Venter, S. M., and E. T. F. Witkowski. 2013. Using a deterministic population model to evaluate population stability and the effects of fruit harvesting and livestock on baobab (Adansonia digitata L.) populations in five land-use types. Forest Ecology and Management 303:113-120. http://dx.doi.org/10.1016/j.foreco.2013.04.013 
Villalobos, M. P., and M. A. Bagno 2012. Avian frugivores feeding on Mauritia flexuosa (Arecaceae) fruits in Central Brazil. Revista Brasileira de Ornitologia 20:26-29.

Wahlén, C. B. 2017. Opportunities for making the invisible visible: towards an improved understanding of the economic contributions of NTFPs. Forest Policy and Economics 84:11-19. http://dx.doi.org/10.1016/j.forpol.2017.04.006

Wakelin, J., A.-L. Wilson, and C. T. Downs. 2013. Ground cavity nest temperatures and their relevance to Blue Swallow Hirundo atrocaerulea conservation. Ostrich 84:221-226. http://dx.doi. org/10.2989/00306525.2013.859640

Welford, L., S. Venter, C. Dohse, and I. Chibaya. 2015. Harvesting from the Tree of Life. Pages 90-102 in C. Shackleton, A. Pandey, and T. Ticktin, editors. Ecological sustainability of non-timber forest product harvesting: case-studies and dynamics. Earthscan, London, UK.

West, H. G. 2007. Ethnographic sorcery. University of Chicago Press, Chicago, Illinois, USA. http://dx.doi.org/10.7208/ chicago/9780226894126.001.0001

Williams, V. L., A. B. Cunningham, A. C. Kemp, and R. K. Bruyns. 2014. Risks to birds traded for African traditional medicine: a quantitative assessment. PLOS ONE 9(8):e105397. http://dx.doi.org/10.1371/journal.pone.0105397

Whiting, M. J., V. L. Williams, and T. J. Hibbitts. 2013. Animals traded for traditional medicine at the Faraday market in South Africa: species diversity and conservation implications. Pages 421-473 in R. R. N. Alves and I. L. Rosa, editors. Animals in traditional folk medicine: implications for conservation. Springer, Heidelberg, Germany.

Worm, B., and R. T. Paine 2016. Humans as hyperkeystone species. Trends in Ecology \& Evolution 31:600-607. http://dx.doi. org/10.1016/j.tree.2016.05.008

Wright, S. J. 2003. The myriad consequences of hunting for vertebrates and plants in tropical forests. Perspectives in Plant Ecology, Evolution \& Systematics 6:73-86. http://dx.doi. org/10.1078/1433-8319-00043

Yeaton, R. I. 1988. Porcupines, fires and the dynamics of the tree layer of the Burkea africana savanna. Journal of Ecology 76:1017-1029. http://dx.doi.org/10.2307/2260630

Zona, S. 2005. Additions to "a review of animal mediated seed dispersal of palms." The Virtual Herbarium, Coral Gables, Florida, USA. [online] URL: http://www.virtualherbarium.org/ palms/psdispersal.html 